\title{
A place I could call my own
}

\author{
Queer Malays and the meanings of 'home'
}

\section{Collin Jerome}

To cite this article: Collin Jerome (2020): A place I could call my own, Indonesia and the Malay World, DOI: $10.1080 / 13639811.2020 .1751948$

To link to this article: https://doi.org/10.1080/13639811.2020.1751948

\section{Published online: 13 May 2020.}

Submit your article to this journal

Џ Article views: 3

Q View related articles ¿

View Crossmark data $₫$ 


\title{
A PLACE I COULD CALL MY OWN Queer Malays and the meanings of 'home'
}

\author{
Collin Jerome
}

\begin{abstract}
This article explores the meanings of 'home' for queer Malays in Malaysia through an analysis of the central gay Malay male character in Azwan Ismail's story, Tiada sesalan (No regrets). Drawing upon studies of home by feminist and queer geographers, the article examines the character's notions of 'home' and how these notions are constructed across time and space. The findings show that 'home' has been conceived of in many ways: as (1) a material-imaginative space; (2) a site of identity and power; and (3) a multi-scalar construct. The character has, for the most part of his life, been engaged in the process of queering home through which he developed a queer sense of 'home' and identity. This, however, has not been an easy task because the home is a powerful site that can both facilitate and complicate the process.
\end{abstract}

\section{KEYWORDS}

critical geography; home; identity; Malay; queer

\section{Introduction}

This article investigates what the concept of 'home' means to queer Malays in Malaysia through an analysis of the central gay Malay male character in Azwan Ismail's story, Tiada sesalan (No regrets). The article begins with a discussion of the key terms and the story under study. This is then followed by a description of the theoretical framework for analysis and the meanings of 'home' for Malays in Malaysia. It then analyses the character's constructions of 'home' and identity across time and space, and concludes with a summary of findings and recommendations for future research.

Two key terms are used in this article, namely, 'queer' and 'home'. The term 'queer' is employed in several ways: as (1) a position; (2) a strategy; (3) a verb; and (4) an umbrella term. The first two follow the use of 'queer' by Rivera-Servera (2012: 27), to describe what it means 'to be queer' and 'to act queer': the former reflects the position taken up by individuals of non-normative sex/gender, while the latter represents the strategies utilised in accordance to that position. The strategies, which may include modes of speaking, styles of dressing, and bodily dispositions, are commonly used by these individuals to navigate their lives in this heteronormative world. 'Queer' is also used as a verb to describe the act of queering that underlies what it means to be queer and to act queer. McCann and Monaghan (2020:3) posit that to undertake 'queering', one needs to deploy 'queer' as a verb that signifies the act of subverting and undermining norms or expectations. Put into context, individuals of non-normative sex/gender engage in the act of queering 